\title{
TYPES OF MAZES
}

\author{
Rodicae uxori suaviter
}

\section{INTRODUCTION}

The labyrinth is beyond any doubt one of the most fascinating aspects of human societies. Though its magic forms and implications are well known and have been the subject of important analyses - the best known being perhaps $P$. Santarcangeli's Il libro dei labirinti now with many translations in various languages, lately rediscussed by Krzak (1985) - there still are unrevealed aspects, some perhaps improperly understood. It is our purpose to examine here (1) the pre-Indo-European (hereafter pre-IE) family of the fundamental Greek form labýrinthos (a term sometimes labelled 'Mediterranean', which is not ultimately incorrect), (2) the pre-IE family of English forms maze/amaze and their unexpected south and southeast European parallels (noticed a long time ago, but unconnected to this context), and (3) the interpretation of the available data in the sense that the labyrinth was initially a projection of the Neolithic Goddess's sacred body.

Our investigation deals especially with linguistic data but will equally refer to archaeological and cultic aspects. It is our hypothesis that the initial meaning of labyrinthic structures was not only initiatic but reflected the inner meanders of Goddess's body, i.e. her sacred bowels. The purpose of this article is to substantiate this assertion.

\section{Greek form labýrinthos and its family}

After minute and not always easy investigations it is quite obvious now that Gr. labýrinthos belongs to a pre-IE root ${ }^{*} L-B$ - ( ${ }^{*} L a B-,{ }^{*} L a P$-, etc.) 'stone, slab, cliff*. This root is very well represented on a large area in south and south-east Europe, and even in western Europe. ${ }^{1}$ Table 1 and its notes summarize the data available so far; we expect additional data to complement present-day knowledge. Yet it is already clear that the primitive meaning of the labyrinth or, better, of the labyrinth common to the Greek-Aegean world was 'stone structure', more exactly 'structure of big stones'. The word is indeed a compound of the typ *LaB-UR-inthos, i.e. root ${ }^{*} L a B$ - 'stone, cliff' and *OR-/*UR-'big, huge', already analyzed by various lin-

1 Given the limited purpose of this study, the analysis of the reasons why such pre-IE roots are so well represented in a large area and in strikingly similar forms' shall be made on another occasion as we tried in our Byzantion, MS. 
Table 1

The general distribution of the forms derived from the pre-Indo-European root ${ }^{*} L-B-/{ }^{*} L-P$ - 'stone, cliff, hill'.

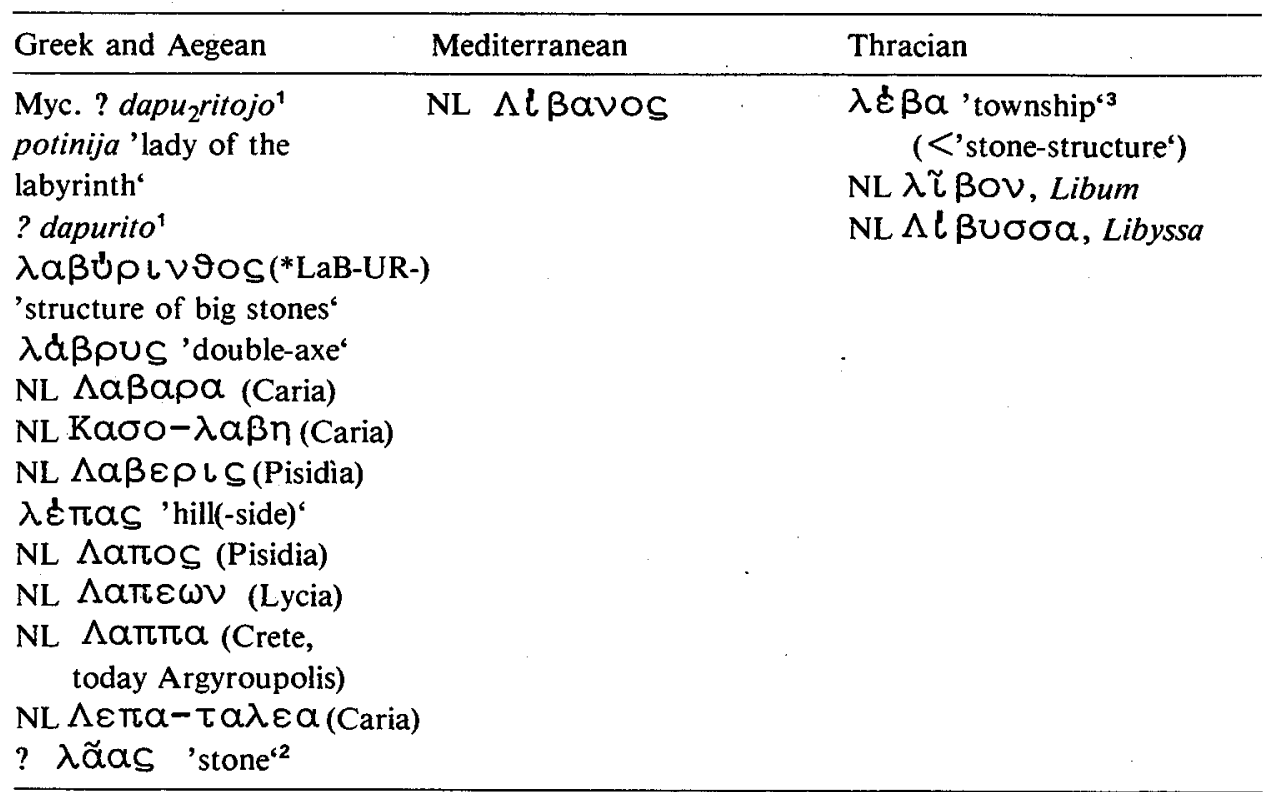

\begin{tabular}{|c|c|c|}
\hline $\begin{array}{l}\text { Italic (Etruscan, } \\
\text { Latin, Italian) }\end{array}$ & Iberian & French \\
\hline $\begin{array}{l}\text { Lat. labrum } \\
\text { NL Lābro> Livorno } \\
\text { Etr. Labrius, Laberius } \\
\text { Puliese labbi 'coltello' } \\
\text { Sard. làera 'pebble', } \\
\text { Camp. làvera } \\
\text { Friul làvara 'slab' } \\
\text { Etr. la' } \emptyset \text { e, Lappa } \\
\text { NL Lepta } \\
\text { Lat. lapis }\end{array}$ & $\begin{array}{l}\text { ML Libana (Castilia) } \\
\text { NPp Labeates (rel. } \\
\text { to Libana) } \\
\text { NL Lebedontia (Avieno) } \\
\text { Iber. *lappa 'cave', } \\
\text { Port. lapa 'id.' } \\
\text { NL } \Lambda \text { a } \alpha \tau \iota \alpha\end{array}$ & NL Le Lubéron \\
\hline
\end{tabular}

\section{Notes to table 1}

1 Uncertain because Myc. $p u_{2}$ usually corresponds to Gr. $\varphi U$ and $d a$ is used instead the expected la.

2 In order to be regularly explained in this context, $\lambda$ ãaS should suppose an initial form *lawas $<*$ labas.

3 One of the seven attested Tracian forms for.'township', cf. Paliga 1987. 
guists (Trombetti 1925; Muşu 1981; Paliga 1987; 1989; MS). The primitive meaning 'structure of the big stones' shows that the Aegean-Greek labyrinths were typologically, if not even genetically, close to the megalithic monuments of Western Europe. We shall revert to this aspect in the final part of this paper. But before drawing conclusions it is of much use to analyze in detail Eng. maze whose etymological context is less clear.

\section{English forms maze/amaze and related parallels}

It is well known that no other parallel of Eng. maze has been identified so far, this word being practically unexplained. The only clear connection can be traced to the verb amaze in Middle English still preserving the meaning 'to bewilder, to confuse'. The Old English attested form is the past participle amasod (Skeat 1879; Onions et al. 1969; Morris et al. 1979). Klein's approach (1971), together with the epithet 'probable' to Norw. masast 'to doze off' and Swed. masa'be slow, sluggish' is doubtful, though not impossible, as we shall see below. In Canterbury Tales, the old meaning of amaze is still preserved:

'Ye maze, maze, gode sire, ' quod she,

'This thank have I for I have maad you see;"

'Allas!' quod she, 'that ever I was so kinde!"

'Now, dame,' quod he, 'lat al passe out of minde.'

(Merchant's Tale, v. 2387-2390; quoted from Skeat 1913).

Despite the almost desperate situation concerning the origin of these closely related words, at least one fact is clear: the primitive meaning should have been 'intricate, confused situation“. No other parallels have been found, except Klein's approach quoted above.

The following forms should be considered in this context:

a) A Pre-IE ('Mediterranean') root reconstructed as *mat( $t$ )a 'bushy land, bushiness' has been identified as the etymon of Alb. mandë 'mulberry' (the plant $M o$ rus), from a primitive form *mant-<*matt-, very probably akin to Basque mahats 'grape'. An Apullian form matine 'bushy land' is also attested, also the Italic personal name Matese, Meta (Bertoldi 1931: 258 ff.; Ribezzo 1950).

b) Perhaps (or probably) related to these, a primitive Uralic form *maij $₫$ a'forest ${ }^{\text {* }}$ has been reconstructed, out of which the Lappish muoi $i$ and Finnish metsä are explained, both preserving the primitive meaning. Another primitive Uralic form *mäkt 3 'bush, shrub' has been also supposed for Fin. mätäs, Gen. mättään (Collinder 1957: 115-6, 178; 1960: 407).

c) A particularly interesting word, supporting the facts stated so far and opening further perspectives, is Latvian mats 'hair' which has equally remained unexplained (Fraenkel 1955-1965 s.v. mãtaras 'a stake, a pile; Lidén 1908: 493; both linguists assert that Latv. mats is an obscure word). 
Some Romanian words also accept an explanation in this context, i.e. as derivatives from an old, primitive root having the meaning 'intricate, confuse'. A significant parallel is mat, pl. mate 'gut (s)', 'bowels' together with the verb a ameti (from an older form amăti, cf. Puşcariu 1916-1948: I: 147) 'to make/become dizzy, to stun' which was from the very beginning supposed by the author as the exact parallel of Eng. maze - amaze. But, as this detail has not been noticed so far, a brief discussion is necessary. Thus, Rom. mat(e) is usually compared to Napolitan mattse 'id.' and Logudorese matta 'womb, stomach' for which a Latin form matia is supposed (Meyer-Lübke 1935; in Rosetti 1978: 139 the same solution is accepted, whereas on p. 598 a primitive meaning 'string $/$ ?!/ is suggested).

The facts seem to be very debatable, yet it is obvious that, on the one hand, Lat. matia has not developed further pan-Romance forms but is preserved (better said, is considered to be so) only in Romanian and in two Italian dialects. On the other hand we find that Lat. matia is a 'mot de glossaire' (Ernout-Meillet 1959: 390 - "intestina unde matiarii dicuntur qui eadem tractant aut uendunt"). The origin of Lat. matia is usually considered Gr. $\mu a \tau \tau U n$ name of a delicate and delicious meal stirring the appetite (Ernout-Meillet 1959; Walde-Hofmann 1938-1954: II: 52; Frisk 1960 ff.: II: 185; Chantraine 1968-1980: 672 with further discussions).

Therefore (1) while in Romanian and the Italian dialects the meaning refers to an anatomical detail, i.e. a part of the body, (2) in Latin - as a supposed borrowing from Greek - it clearly refers to cookery. The difference, of course, is not insuperable, knowing that the bowels of different animals are largely used for preparing

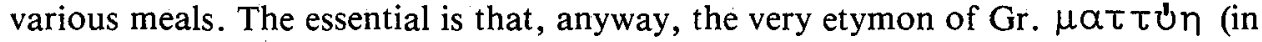
its turn the suggested source of Lat. matia) is obscure, so Pierre Chantraine ultimately supposes 'a term borrowed from Macedonian' (Chantraine 1968-1980: 672 “On pourrait se demander si n'est pas purement et simplement un terme emprunté au macédonien“). But - following this line of thought - Macedonian means a territory closer to the Thracian area, i.e. the substratum language of Romanian, a detail which may ultimately clarify the situation of all these terms. Though the primitive origin of the Greek term may not affect the red thread of our demonstration, we assume that Chantraine's suggestion has a great probability of being correct, especially in the context considered in these pages, opening the perspective of an indigenous term most probably connected to Rom. mat(e), via a Thracian form easily reconstructable as *mats- if a meaning 'intricate, confuse' can be traced back to Gr. $\mu \alpha \tau \tau U n$, the Macedonian-Greek word being therefore another relic of the Mediterranean rot *mat(s)- as identified and analyzed by the Italian scholars.

In what concerns the relation between (1) Lat. matia - Rom. mat(e) and (2) Lat. matia and the dialectal forms mattse and matta, further considerations will be possible after presenting the situation of another word.

Rom. a ameți (a amăti) 'to make or become dizzy, to stun' is still more difficult to explain, three solutions being offered, as follows: 
(1) An obscure term, perhaps an a-development from Slavic mesti, mesto 'dim, confused" (Tiktin 1901-1916): 60; Slavic forms in Miklosich 1886: 189). This etymon is obviously impossible as the details regarding the phonetic changes of Sl. $\rho$ and the group -st-cannot be avoided.

(2) A Latin origin from (sensus) ammittere'to affect the senses', aimed mainly at explaining the dialectal form $a$ améte (in Transylvania), but disconsidering the oldest $a$ amăti, which is a fundamental detail (Săineanu 1929: 22).

(3) The common explanation now is by Lat. *ammattire < mattus 'drunken' (Puşcariu 1916-1948), I: 147; accepted in Coteanu et al. 1975: 31 also in Meyer-Lübke 1935: 445/5428, in the latter case without the Romance parallels as presented by Puşcariu, i.e. It. matto 'mad, crazy', Fr. mat 'powerless, weak' which are considered separately, under entry 5401 and 5424 respectively).

In our opinion these explanation should be now abandoned. They are not supported either by phonetic analysis or by certain mythological implications as shown below.

The Romanian words already analyzed, i.e. mat(e) 'bowels' and a ameti 'to

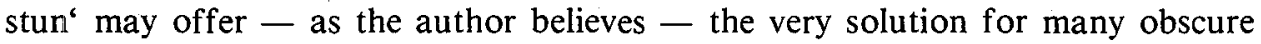
facts. In other words, Rom. matt(e) - a ameti is the exact parallel of Eng. maze/to amaze, both in form and meaning, from a primitive root ${ }^{*} M a T(T)-$, very probably also ${ }^{*} M a T s$ - 'intricate, confused', already identified and analyzed by the Italian scholars Bertoldi and Ribezzo. For a complete analysis two details should be mentioned.

(a) The spelling of Eng. maze/to amaze is very well clarified by the Rom. form as well as by Basque mahats; both arguably preserve the original phoneme $/ \mathrm{ts} /$, which, in the case of Romanian, should be accepted as existing in Thracian the substratum language of Romanian. ${ }^{2}$ Indeed, the same phoneme should be postulated for the oldest form which resulted in Eng. maze/amaze. It is known that in Old and Middle English the situation of $s$ and $z$ is confusing, sometimes one letter being used instead of the other, sometimes $z$ being used for denoting a phoneme like /ts/ (e.g. Pyles 1964: 38-39). This original phoneme is also witnessed by Latvian mats (see below).

(b) Both Rom. a ameti and Eng. amaze denote the same prefix $a$. The parallel is striking yet interpretable without referring to hazard. It is to observe that in many European languages the prefix $a$ - may be variously explained. In English, there was a superposition of different influences, in this case being a reflection of Old English $a$-. On the other hand, in Romanian $a$-represents the evolution of Lat. ad. Yet in both cases it is better to suppose a primitive pre-Germanic and

2 The problems connected to the Thracian phonetic changes are too complex to be considered here. We tried a brief but comprehensive analysis in Byzantion, MS. For the very case discussed here, it is relevant to note that other Thracian words preserved in Romanian exhibit the same phoneme $/ t s /$ which arguably was original, e.g. tap 'he-goat', very probably another pre-IE relic in Romanian. 
pre-Celtic formation (in Britain) and pre-Thracian (in Romanian) of the type *a-mats-, later assimilated to more productive derivative means.

In this perspective, the relation between Romanian, on the one hand, and the Italian and Macedonian-Greek terms on the other, should be reconsidered. The alternatives are:

(1) Either there is no immediate connection between Rom. mat(e) and the Italian dialectal forms mattse and matta from Lat. matia in its turn from Gr. $\mu \alpha \tau \tau U \eta$, in which case the similarity between the Macedonian-Greek forms and the Thracian-Romanian ones may be accounted for in terms of a 'Balkanic' element.

(2) Or, especially if considering the meaning of the Italian forms, one is to suppose an East-Romance influence towards the West, the Latin form matia therefore has no direct connection either with Rom. mat or with the Italian forms. In this case too, a primitive relationship between the Rom. words (via Thracian) and the Macedonian-Greek forms should be accepted.

No definite answer can be offered here, mainly because it is beyond the purpose of this paper, secondly because it requires a comprehensive review of other Balkanic elements migrated to the West, ${ }^{3}$ thirdly because the very situation of Lat. matia and

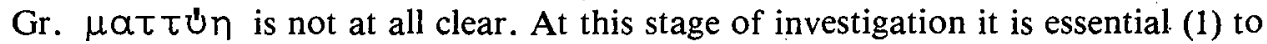
note the relevant correspondence between Romanian and English, and (2) to note the correspondence between these forms and the other ones presented above, all preserving a primitive meaning 'intricate, confused'.

In order to have a clearer image of these terms, it is interesting to revert to the obscure Latvian mats ' hair' now comparing it to another Romanian word: $m o t(t=$ ts) 'tuft of hair'. The similarity (if not quasi-identity) is striking and, once again, cannot be the result of hazard. The $a / o$ vowel grade is easily explainable. To approach these two words is all the more necessary because it has not been observed so far. Just like Latv. mats, Rom. mot has remained unexplained, being one of the very numerous Romanian words without etymon. The word appears also as the name of a population living in the West Carpathians in an isolated and very conservative area. These people are characterized by a specifically cut tuft of hair. The same word seemingly appears as the name of a Macedo-Romanian ethnic group: the Motani (Puşcariu 1916-1948, Papahagi 1924: 22-28; Paşca 1927: 1012-10134).

In addition to the parallel Rom. mot - Latv. mats, Romanian may ultimately clarify the facts presented by Klein (see above), namely an approach of Eng. maze/

3 Some Romanian and Thracian words spread in the Balkans and East Europe are observed in Russu 1981: $242 \mathrm{ff}$. Other examples in our Bvzantion, Ms.

4 A folk belief connected to hair is noted: if a wolf sees someone in the morning, this person will surely become hoarse, against which the person must hold the tuft of hair on his head. For the magic values of hair, cf. Judges, 14-16 (Samson and Delilah), also Brüder Grimm's tale Rapunzel, and finally Loreley (or Lorelei) in the German folklore. 
amaze to Norw. masast 'to doze off' and Sw. masa 'to be slow, sluggish'. In this perspective, we cannot avoid the Romanian verb a motal $i$ 'to doze off $\mathrm{f}^{\circ}$, the root of which is identical to mot 'tuft of hair'. This similarity probably has been considered as mere hazard. Anyway, a motăi is another enigma of the Romanian vocabulary. Finally, I should note the verb a mototoli 'to crumple', seemingly a reduplicated form reductable to mot-mot-ol-, with a simplified pronunciation to mot-ot-ol(further examples of such simplified reduplications are considered in our MS Byzantion). We again have no reason to consider all these forms as the result of mere hazard but as evidence of the real existence of an old non-IE root ${ }^{*} M a T(T)$-, ${ }^{*} M a T(s)$ (eventually with a parallel with $o$-vowel grade, which could result later as well by phonetic evolution).

Some remarks on Eng. maze/amaze and Rom. maț(e)/ameți

The situation of the words discussed and covering a large area of different linguistic structure (Germanic, Romance, Hellenic, Baltic, Iberian) may be summarized thus:

(a) The primitive pre-IE root may be fairly well reconstructed as ${ }^{*} M-T-,{ }^{*} M-T S$ (*MaTT-, *MaTs-, maybe also $\left.{ }^{*} M o T s-\right)$ 'intricate, confuse'.

(b) Eng. maze/amaze (*mats-/a-mats-) answers Rom- maț(e)/ameți (amăti) 'bowels/ to stun', the latter via a Thracian form *mats-/*a-mats- (*a-m a ts-). Another parallel seems to be Eng. amaze, Norw. masast 'doze off', Sw. masa 'be slow' and Rom. a motă $i$ 'doze off', the latter related in a way or another to mot'tuft of hair'; such a relationship cannot be understood but in the context of the primitive meaning of the root: 'unclear, confuse'. Rom. a mototoli (reduplicated) should also be discussed in this context.

(c) Out of all senses, i.e. (1) maze, (2) bowels, (3) to amaze, to stun, (4) to doze off, (5) bush, (6) hair, tuft of hair, different languages have preserved one or more meanings (yet never all these meanings, according to our investigations). In the light of the data available so far, Romanian seems to preserve most of these meanings: four of six, but the results are, of course, incomplete and new data may enrich the list.

(d) The sense 'bush, bushiness' is a group apart represented by Alb. mandë (from *mant-<*matt-) 'mulberry', Italic mata, matta, matine 'bushy land, bushiness', Basque mahats 'grape', possibly Uralic *mäkt3 'bush', *maijむa 'forest'.

(e) Gr. $\mu \alpha \tau \tau U n$ 'a type of meal, a sausage' has an obscure position, with more or less of an affinity with all the other forms discussed, first of all to Rom. matt(e) 'bowels' (via Thracian, a substratum element in Romanian). 


\section{Pre-Indo-European Relics}

All these terms are relics of a non-IE language (or closely related languages) once spoken in Europe before Indo-Europeanization. The phonetic changes as well as the meanings do not follow the laws known in the IE idioms. The situation of the Uralic forms *maijঠ $a$ and ${ }^{*} m a \ddot{a} k 3$ is uncertain; they most probably belong to the context discussed here, but a final solution may be offered only when other correspondences between the Uralic family and the pre-IE substratum have been identified and analyzed. In this view it is perhaps better to reconstruct no primitive Uralic forms but to postulate a borrowing from an old non-Uralic (and non-IE) idiom.

Undoubtedly, most of the words belonging to the pre-IE root ${ }^{*} M-T(T)$ - 'confused, labyrinthic' had a magic symbolism. Eng. maze is a typical example. Others had, or still have, implicit magic values, such as the creeds connected to hair. ${ }^{5}$ All these forms may be a linguistic approach to a better understanding of the 'pre-IE phenomena', to the numerous aspects linked to the survival of pre-IE terms until modern times. But a better understanding of this symbolism may be achieved if we refer to the 'labyrinthic phenomenon'.

Gr. labýrinthos, Eng. maze, Rom. maț(e)

If there is now little doubt that the initial meaning of Gr. labýrinthos was 'structure of huge stones' and also little doubt that the first meaning of Eng. maze was 'intricate, confused, labyrinthic' (meaning also shared by Rom. mate), what could be the common features of both these semantic fields, apparently distant (and distinct), and belonging to different cultural areas?

One first common feature is obvious: both semantic fields are well represented in a large area of Europe, in the first case being forms derived from a primitive preIE root ${ }^{*} L-P$ - 'stone, cliff', in the second case forms derived from a primitive (equally non-IE) root ${ }^{*} M-T(T)-,{ }^{*} M-T(s)$.

Another common feature - and the most important - is that all the forms analyzed reflect a pre-IE heritage. In order to understand the typological context of these pre-IE (Neolithic) cultures, it is imperative to observe that they were dominated by female deities, as abundantly witnessed by archaeological evidence (Gimbutas 1982). Similarly, the megalithic monuments of Western Europe also copied the Goddess's body: the vulva, vagina and uterus. The origin of this representation is undoubtedly in Upper Palaeolithic. Several figures on the walls of the megaliths have clear parallels in the Neolithic cultures of south-east Europe (Gimbutas 1985).

5 Taierea motului 'tuft-cutting' is a traditional feast accomplished a year after a baby's birth. It is in use all over Romania and obviously reflects an archaic, pre-Christian creed. 
Table 2

Survey of the forms derived from the pre-Indo-European root ${ }^{*} M-T(T)-\left({ }^{*} M a T-/\right.$ $M A T S-,{ }^{*} M o T-/ M O T s-$, etc.) 'intricate, confuse, labyrinthine'.

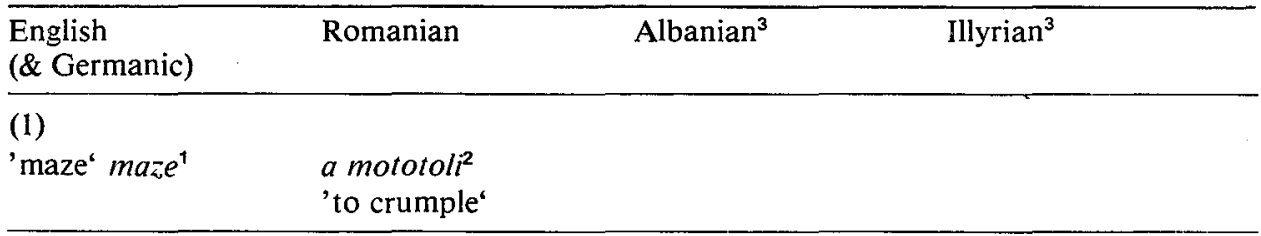

(2)

$\begin{array}{ll}\text { 'bowels' } & \text { mat(e) } \\ \text { 'bowels, guts }\end{array}$

(3)

'amaze, amaze $\quad$ ameți, amătsi

$\operatorname{stun}^{\prime}(a-m a z e) \quad(a-m a t)$

(4) Norw.

'doze masast 'doze a motăi 'doze off'

off' off'; Swed.

masa 'be slow'

(5)

\begin{tabular}{lll}
$\begin{array}{l}\text { 'bush, } \\
\text { tree' }\end{array}$ & $\begin{array}{l}\text { mandë 'mulberry } \\
\left({ }^{*} \text { mant }-<{ }^{*} \text { matt }\right)\end{array}$ & $\begin{array}{l}\text { Dalmatid } \\
\text { 'forested hills }\end{array}$ \\
\hline
\end{tabular}

(6)

'hair' mot 'tuft of hair'

Motani (name of some

inhabitants)

Notes to Table 2

1 From *mats- (see the main text) which answers Rom. mat(e) $(t=\mathrm{t} s$ ).

2 Reduplicated form *mot-mot-ol>mot-ot-ol.

3 Illyrian is not considered here as 'proto-Albanian' (or Albanian neo-lllyrian) from reasons which cannot be developed here.

4 Further discussions in 'Linguistica' 28 (1988): 105-108.

5 '?' refers to the uncertainty regarding the ultimate source of both Greek and Italian dialectal forms (Macedonian in Greek? indigenous in Italian?). 
Table 2 (continued)

\begin{tabular}{llll}
\hline Italic & Latvian & Uralic & Basque \\
\hline
\end{tabular}

Lat. matia (? Gr.

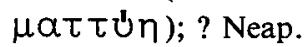

mattşe 'bowels's , Logud.

matta 'womb, stomach'

\begin{tabular}{lll}
\hline Apulian matine 'bushy & ${ }^{*}$ maiða 'forest: & mahats \\
land', PersN Matese, & Lapp muoi $i$, Fin. & 'grape \\
Meta & metsä; mäkt3 'bush, $\quad(\text { mats- })^{6}$ \\
& Fin. mätäs & \\
\hline
\end{tabular}

mats 'hair'

In this view it becomes clear that the archaic symbolism of the megaliths, labyrinths and bowels is now obviously derived from Upper Palaeolithic / Early Neolithic references to the Goddess's sacred body in her various hypostases: Creatrix (LifeGiver) or Death-Giver. If the megalithic monuments tried to copy the Goddess's body (just like certain caves chosen for ritual practices), the labyrinth (i.e. 'the structure of "huge stones') copied the Goddess's bowels (Fig. 1). The parallel Eng. maze - Rom. mate is relevant and inevitable. The fact that the labyrinth was sometimes viewed as 'the house of the entrails' is once again relevant (Santarcangeli 1974, with a sub-chapter thus entitled). The association between the labyrinth - in its later, derived sense of 'intricate, confused" - and bowels is obvious and based on a profound knowledge of the human body. It is therefore no wonder that in various cultural areas (Southeast Europe, Western Europe, Iberia, Italy) the labyrinth - in its endless versions - was (and perhaps still is) continuously imbued with magic powers.

Notes to Table 2 (continued)

6 According to present-day knowledge, it may be assumed that $h$ is not etymological. 


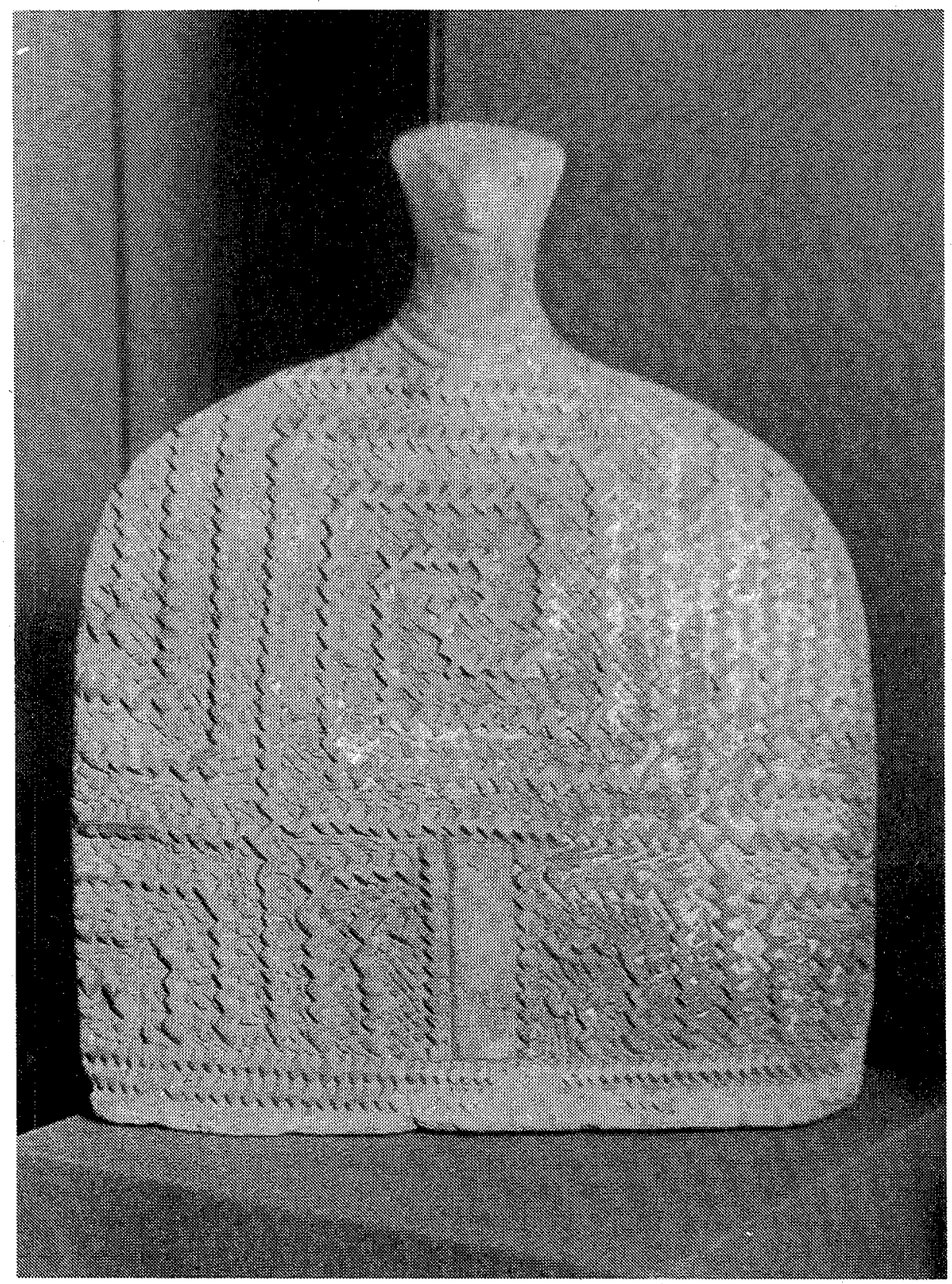

Fig. 1 Model of a temple discovered at Vădastra, Olt district. Comparative calibrated radiocarbon chronology for the corresponding layer indicated first half of the 5 th millenium B.C. Upper part of the figurine is reconstructed. Labyrinthic model incised on the body corresponds to the facts revealed hy linguistic analysis. (Courtesy National Museum of History and Archaeology, Bucharest). 


\section{CONCLUSIONS}

In the light of the data presented here, we hope it has become evident that the labyrinth initially functioned as a cult place, as so well represented in the Aegean (cf. Rutkowski 1972), and more exactly a cult place similar to the megalithic monuments of Western Europe which copied the Neolithic Goddess's body. It is only later - when the initial meaning was lost, as always happens in the history of culture that the labyrinth became associated with other functions and was interpreted mainly as a way of redemption (cf. Krzak 1986).

The labyrinth was initially another form of revering the Neolithic Goddess and any interpretation of its meanings and functions should comply with the age when these genuine cult places were built and when they had their meaning, later forgotten or reinterpreted according to the fashion of the day.

To commemorate the labyrinth is to commemorate the beginnings of European cult activities which go back in time to the Upper Palaeolithic or may be still earlier.

\section{REFERENCES}

Alessio, Giovanni 1935-1936. Le basi preindo-europee KAR(R)A/ GAR(R)A 'pietra'. Studi Etruschi IX: 133-152 and X: 165-189.

Arnal, Jean 1976. Les statues-menhirs, hommes et. dieux. Toulouse: éd des Hespérides.

Baylon, Christian, Paul Fabre 1982. Les noms de lieux et de personnes. Introduction de Ch. Camproux. Poitiers: Nathan.

Beloiu, Valentin 1987. Megaliți în Calimani? Stiința şi tehnica (Bucharest), no. 1, p. 38.

Bertoldi, Vittorio 1933. Preellenico $\beta \& \tau O S, \mu \alpha \nu \tau l \alpha$ 'cespuglio, rovo' e preromanzo matta, mantia 'cespuglio, rovo'. Glotta 22: 258-267.

Chantraine, Pierre 1968-1980. Dictionnaire étymologique de la langue grecque. Paris: Klincksieck.

Collinder, Björn 1957. Survey of the Uralic Languages. Stockholm-Uppsala: Almqvist \& Wiksell.

Collinder, Björn 1960. Comparative Grammar of the Uralic Languages. Stockholm-Uppsala: Almqvist \& Wiksell.

Coteanu, I., L. Seche, M. Seche (eds.) 1975. Dictionarul explicativ al limbii române $(D E X)$. Bucureşti: Editura Academiei.

Dečev, Dimitar, 1957. Die thrakischen Sprachreste. Wien: Österreichische Akademie der Wissenschaften.

Devambez, Pierre, R. Flacelière, P.M. Schuhl, R. Martin 1970. Enciclopedia civilizatiei grecești. București: Meridiane (French original: Dictionnaire de la civilisation grecque, Paris: F. Hazan éd. 1966). 
Ernout, A., A. Meillet 1959. Dictionnaire étymologique de la langue latine, 4th. ed. Paris.

Faure, Paul 1977. Viaţa de fiecare zi în Creta lui Minos. Bucureşti: Eminescu (French original: La vie quotidienne en Crète au temps de Minos, 1500 av. Jésus-Christ. Paris: Hachette 1973).

Fraenkel, Ernst 1955-1965. Litauisches etymologisches Wörterbuch. Heidelberg: Carl Winter.

Frisk, Hjalmar 1960-1972. Griechisches etymologisches Wörterbuch, I-III. Heidelberg: Carl Winter.

Gimbutas, Marija 1982. The Goddesses and Gods of Old Europe. London: Thames and Hudson.

Gimbutas, Marija 1985. The Megalithic Tombs of Western Europe and their Religious Implications. The Quaterly Review of Archaeology 6, 3: 1-8.

Gimbutas, Marija MS. Spirituality of Old Europe (in Romanian translation as a part of the volume Civilizatie si cultura București: Meridiane 1989).

Klein, Ernst 1971. A comprehensive etymological dictionary of the English language. Amsterdam-London-New York: Elsevier.

Krzak, Zygmunt 1985. The Labyrinth - a path of initiation. Archaeologia Polona 24: $135-148$.

Lidén, E. 1908. Baunamen und Verwandtes. Indogermanische Forschungen 23: 485-509.

Meyer-Lübke, W. 1935. Romanisches etymologisches Wörterbuch. 3rd. ed. Heidelberg: Carl Winter.

Miklosich, Franz 1886. Etymologisches Wörterbuch der slavischen Sprachen. Wien.

Morris, William 1979. (ed.) The American Heritage Dictionary of the English Language (AHD). Boston: Houghton Mifflin Co. (first print: 1969).

Muşu, Gheorghe 1981. Lumini din departari. Civilizatiii prehellenice şi microasiatice. Bucureşti: Editura ştiinţifica şi enciclopedica.

Onions, C.T. 1969 (ed.). The Oxford Dictionary of English Etymology. Oxford.

Paliga, Sorin 1987. Thracian Terms for 'township' and 'fortress', and related placenames. World Archaeology 19, 1: 23-29.

Paliga, Sorin 1989. Oraş. fascinaţia unei etimologü: "Noi Tracü“ 18 (no. 172, Feb.): 16-21. Paliga, Sorin. MS. Byzantion.

Papahagi, Tache 1924. Cercetari în Munţii Apuseni. Grai şi suflet 2: 22-88.

Paşca, Ştefan 1927. Commentary on Papahagi 1924. Dacoromania 4: 1009-17.

Pușcariu, Sextil (ed.) 1916-1948. Dicționarul Academiei Române (DA), A-L. Bucureşti (beginning with letter $\mathrm{M}$, the editors are I. Iordan, Al. Graur, I. Coteanu). Work still uncompleted.

Pyles, Thomas 1964. The origins and development of the English language. New York.

Renfrew, Colin 1979. Problems in European Prehistory. Edinburgh: University Press.

Ribezzo, Francesco 1950. Di quattro nuove voci mediterranee già credute celtiche: ébhura 'tasso', leme 'olmo', támara 'uva di sepe', sámara 'fosso d'acqua'. Revue internationale d'onomastique 2, 1: 13-25. 
Rosetti, Alexandru 1978. Istoria limbii române, 2nd. ed. Bucureşti: Editura ştiințifica şi enciclopedica.

Rostaing, Charles 1950. Essai sur la toponymie de la Provence. Paris: éd. d'Artrey. Russu, I.I. 1981. Etnogeneza românilor. Bucureşti: Editura ştiinţifica şi enciclopedica.

Rutkowski, Bogdan 1972. Cult Places in the Aegean World. Wroclaw: Ossolineum (Bibliotheca Antiqua X). Reprinted: 1986 - New Haven-London: Yale University Press.

Santarcangeli, Paolo 1974. Cartea labirinturilor, I-II. Bucureşti: Meridiane (Ittalian original: Il libro dei labirinti, Firenze: Vallechi ed. 1967).

Şaineanu, Lazar 1929. Dicționarul universal al limbei române, 6th. ed. Craiova.

Skeat, W.W. 1879. An etymological dictionary of the English language. Oxford (many subsequent reprints).

Skeat, W.E. (ed.) 1913. The Complete Works of Geoffrey Chaucer. Oxford.

Thomas, Julian, Alasdair Whittle 1986. Anatomy of a tomb - West Kennet revisited. Oxford Journal of Archaeology 5(2): 129-156.

Tiktin, H. 1903-1916. Rumänisch-deutsches Wörterbuch. Bucureşti.

Trombetti, Alfredo 1925. Saggio di antica onomastica mediterranea. Arhiv za arbanasku starinu, jezik i etnologiju 3: 1-116.

Walde, Alois, J.B. Hofmann 1938-1954. Lateinisches etymologisches Wörterbuch, 3. neubearbeitete Auflage, I-III. Heidelberg: Carl Winter.

Rezumat

TIPURI DE LABIRINT

Studiul analizează două tipuri de labirint care stau la baza culturii europene. Unul este reprezentant de gr. labýrinthos, un cuvînt compus din elemente pre-indo-europene destul de clar analizabile: rădăcinile *LaB-'piatră, lespede;, *-UR- 'mare, uriaş' si sufixul -(i)nthos. Labirintul egeean a fost aşadar la începuturi 'structură de lespezi uriaşe'. Celălalt tip se bazează pe ideea de 'confuz, încîlcit' și reprezintă rădăcina, de asemeni pre-indo-europeană, ${ }^{*} M a T(T)$ - 'încîlcit, confuz', analizată în detaliu, plecînd de la paralela, deloc întîmplătoare, eng. maze/amaze, rom. mal/ameti la care se adaugă numeroase alte formc răspîndite pe un areal vast, incluzînd Tara bascilor, spatiul egeo-carpatic si chiar limbile uralice. Ambele tipuri de labirint corespund unor credinte arhaice legate de venerarea divinitătilor feminine din neolitic. 